\title{
大腿骨近位部骨折の術後に発症した偽膜性大腸炎
}

\author{
河 村 好 香* 萩 原 博 嗣* 久我 尚 之* 寺 本 全 男* \\ 田中智 顕* 花田麻須大* 中川憲 之* 古 谷 明子**
}

\section{Pseudomembranous Enterocolitis after Surgery for Proximal Femoral Fracture}

Yoshika Kawamura*, Hiroshi Hagihara*, Naoyuki Kuga*, Masao Teramoto*, Tomoaki Tanaka*, Masuo Hanada*, Noriyuki Nakagawa*, and Akiko Furutani**

\begin{abstract}
整形外科領域において，抗生物質の使用により引き起こされる偽膜性大腸炎は高齢者にとって重要な合 併症の一つである.

当科にて 2006 年 9 月から 2007 年 8 月までに大腿骨近位部骨折に対し手術を行つた 95 症例について調 查した. 年齢は 65 歳から 98 歳, 平均 80.8 歳であった.このうち, 偽膜性大腸炎と診断されたものは 8 症例であった。 5 例はバンコマイシンおよびメトロニダゾール内服により治癒したが， 1 例は再発し 2 例 が重症化し死亡した。同時期に同一病棟内で多発した原因は, 術後予防的抗菌薬として広域スペクトラム の抗生物質を選択していたことと院内感染の可能性が考えられた。
\end{abstract}

Pseudomembranous enterocolitis caused by administration of antibiotic prophylaxis is a serious complication for elderly patients. We reviewed 95 cases who had surgery for proximal femoral fracture between September 2006 and August 2007. The mean age of the cases was 80.8 years (65 to 98). Eight cases were post-operatively diagnosed with pseudomembranous enterocolitis, of which six were cured with oral administration of vancomycin and metronidazol, and two died with progressive systematic infection. We suspect CPZ/SBT was associated with the prevalence of pseudomembranous enterocolitis.

Key words : pseudomembranous enterocolitis (偽膜性大腸炎), proximal femoral fracture (大腿骨 近位部骨折), antibiotics medication (抗生物質投与), nosocomial infection (院内感染)

\section{は じ め に}

大腿骨近位部骨折は，高齢者に多く発症するが，体 力面や併存症の観点から, 術後に様々な合併症を起こ すことが多く, 偽膜性大腸炎もその一つである. 偽膜 性大腸炎とは, 抗生物質使用により腸内細菌叢が破綻 し, Clostridium difficile (以下 C. difficile) が大量 に繁殖し引き起こされる腸炎で, 主症状は下㾥, 腹痛, 発熱である. 当科においての 2006 年 9 月から 2007 年 8 月までの偽膜性大腸炎の発生状況を調查し原因を考 察した.

\section{対象と方 法}

2006 年 9 月から 2007 年 8 月までの一年間に当院に て大腿骨近位部骨折に対し手術を行った 65 歳以上の 患者について, 抗生物質の使用之偽膜性大腸炎の発生 状況を調查した。対象は男性 13 例, 女性 82 例の 95 症例で, 手術時年齢は 65 歳から 98 歳, 平均 80.8 歳 であった。使用した抗生物質は CPZ/SBT が 73 例, CEZ が 17 例, CTM が 3 例, ABPC/SBT が 1 例, $\mathrm{ABPC} / \mathrm{SBT}+\mathrm{CLDM}$ が 1 例であった。抗生物質の一 日量は，肺炎を合併した 1 例を除き $1 \mathrm{~g}$ から $3 \mathrm{~g}$, 投 与日数は 2 日から 4 日であった（表 1$)$.

\footnotetext{
* 佐世保共済病院整形外科 Department of Orthopedic Surgery, Sasebo Kyousai Hospital, Nagasaki, Japan

***央臨床検査科 Department of Laboratory Medicine, Sasebo Kyosai Hospital, Nagasaki, Japan
} 
結

果

Dale らによる診断基準 ${ }^{1)}$ (表 2）に準じ，診断され た偽膜性大腸炎患者は 95 例中 8 例であった（表 3). 8 例中 7 例が CPZ/SBT $2 \mathrm{~g} /$ 日を 2 日間使用していた. 1 例は誤嚥性肺炎の治療経過中に手術を行ったため, $\mathrm{ABPC} / \mathrm{SBT}+\mathrm{CLDM}$ を術前 7 日間術後 14 日間使用 していた． 8 例中 5 例が軽快したが，1例が再発し，2 例が重症化し死亡した。

症例 1

93 歳女性. 自宅で生活し, 補助具を使用せず数十 $\mathrm{m}$ の歩行が可能であった。自宅の庭で転倒し救急車 にて当科へ搬送された。単純 X 線写真で左大腿骨転 子部骨折を認めた.

翌日 $\gamma$-nail による骨接合術を行った。

術直前から CPZ/SBT $2 \mathrm{~g} /$ 日を 2 日間投与した。 術後 10 日目に泥状便が頻回に出現し, 術後 11 日目に は発熱を認め, C. difficileが産生するトキシンを検

表 1 術後抗生物質の種類と 1 日量, 投与日数

\begin{tabular}{l|c|cc}
\hline \hline \multicolumn{1}{c|}{ 抗生物質 } & 一日量 & 投与日数 & 人数 \\
\hline \multirow{2}{*}{$\mathrm{CPZ/SBT}$} & $2 \mathrm{~g}$ & 2 日 & 72 人 \\
& & 3 日 & 1 人 \\
\hline \multirow{2}{*}{$\mathrm{CEZ}$} & $1 \mathrm{~g}$ & 2 日 & 10 人 \\
\cline { 2 - 4 } & $2 \mathrm{~g}$ & 2 日 & 4 人 \\
& & 3 日 & 3 人 \\
\hline $\mathrm{CTM}$ & $2 \mathrm{~g}$ & 2 日 & 1 人 \\
& & 4 日 & 2 人 \\
\hline $\mathrm{ABPC} / \mathrm{SBT}$ & $3 \mathrm{~g}$ & 7 日 & 1 人 \\
\hline $\mathrm{ABPC} / \mathrm{SBT}$ & $6 \mathrm{~g}$ & 21 日 & 1 人 \\
$\mathrm{CLDM}$ & $1.2 \mathrm{~g}$ & & \\
\hline
\end{tabular}

出する迅速キット Toxin A/toxinB が陽性となった. 偽膜性大腸炎と診断し VCM $2 \mathrm{~g} /$ 日の内服を開始し たが, 術後 12 日目に麻痺性イレウスとなり, 術後 13 日目にエンドトキシンショックにより死亡した. 症例 2

82 歳女性. 自宅で生活し, 歩行器歩行が可能であつ た. ベッドから転落し, 救急車にて当科へ搬送された. 単純 X 線写真で右大腿骨転子部骨折を認め, $\gamma$-nail による骨接合術を行った. 術直前から CPZ/SBT $2 \mathrm{~g} /$ 日を 2 日間投与した.

術後 3 日目に水様性下痢が出現し, 術後 6 日目には $38^{\circ} \mathrm{C}$ 台の発熱を認め, Toxin A/toxinB が陽性であっ た.

乳酸菌製剂の内服投与を行つたが改善は見られず, 術後 11 日目に内科受診し, 大腸内視鏡で偽膜形成が 認められた。内科転科となり，メトロニダゾールの内 服を開始したが，術後 17 日目に全身状態が悪化し， 術後 18 日目にエンドトキシンショックで死亡した.

表 2 Dale らの診断基準 偽膜性大腸炎の診断基準 (1)および(2)のいずれかを満たすこと

\begin{tabular}{|c|c|}
\hline (1) & $\begin{array}{l}\text { ·他に原因が明らかでない下痢 } \\
(24 \text { 時間のうち } 3 \text { 回以上の非固形便が } 2 \text { 日以上 } \\
\text { 続く })\end{array}$ \\
\hline (2) & $\begin{array}{l}\cdot \text { ・トキシン A または B が便中に検出される } \\
\text { ・トキシン産生性の C. difficileが便から培養さ } \\
\text { れる } \\
\text { ・結腸に偽膜形成がみられる (図 1) }\end{array}$ \\
\hline
\end{tabular}

表 3 偽膜性大腸炎の例

\begin{tabular}{c|c|c|c|c|c|c}
\hline \hline 症例 & 年齢 & 性 & 術式 & 使用した抗生物質 & 使用日数 & 転帰 \\
\hline (1) & 89 & 女 & 人工骨頭置換術 & CPZ/SBT & 2 日 & 軽快 \\
\hline (2) & 93 & 女 & $\gamma$-nail & CPZ/SBT & 2 日 & 死亡 \\
\hline (3) & 81 & 女 & $\gamma$-nail & CPZ/SBT & 2 日 & 軽快 \\
\hline (4) & 90 & 女 & $\gamma$-nail & CPZ/SBT & 2 日 & 軽快 \\
\hline (5) & 92 & 女 & $\gamma$-nail & ABPC/SBT, CLDM & 21 日 & 転院 \\
\hline (6) & 82 & 女 & $\gamma$-nail & CPZ/SBT & 2 日 & 死亡 \\
\hline (7) & 87 & 女 & long $\gamma$-nail & CPZ/SBT & 2 日 & 軽快 \\
\hline (8) & 94 & 女 & $\gamma$-nail & CPZ/SBT & 2 日 & 軽快 \\
\hline
\end{tabular}


考

察

偽膜性大腸炎は Compromised hostに抗生物質の 投与を契機として発症することがほとんどであるが, 第三世代セフェム系や CLDM などは腸内の菌交代現 象を起こしやすく, 術後感染予防の抗生物質について は第一世代セフェム系やペニシリン系が推奨されてい $3^{4) 5)}$. 当科では従来の大腿骨近位部骨折のクリニカル パスに， $\beta$-ラクタマーゼ阻害薬配合剤である CPZ/ SBT を設定していたため, 多くの患者に同薬剤を使 用する結果となっていた. 直接の因果関係は不明だが, このことが発症に関与した可能性は否定できない.

偽膜性大腸炎の原因である C. difficile は, 芽胞を 形成するグラム陽性桿菌であり，アルコール類での消 毒は無効であるので, 感染予防のためには流水・せっ けんでの手洗いが唯一有効な手段である. また，医療 従事者を介しての感染だけでなく, リハビリ器具や, 車椅子を介しての感染の可能性も考えられる. 今回の 調査期間中, 5 月末から 6 月にかけて特に多く発症し ていたが，この時期には大腿骨近位部骨折の患者以外 にも発症していた，病棟の同室内で 3 人発症するなど の状況がみられており, 院内感染の可能性が強く考え られる。

確定診断には大腸内視鏡検査は有用な診断法で，偽 膜性大腸炎では結腸に特徵的な偽膜形成がみられる
(図 1). 細菌学的検査として, C. difficileの分離培 養は検体処理, 特殊な培地の使用, 嫌気培養が必要で あるため, 当院ではトキシン $\mathrm{A}, \mathrm{B}$ を検出できる簡 易迅速キットを常用している。しかしトキシン A 陰 性, トキシン B 陰性の分離例もあり得ること, 分離 培養と比較してやや感度が低いことから，偽膜性大腸 炎を強く疑う場合は, 分離培養検査を追加する必要が ある.さらに，今回のように施設内集団発生の可能性 がある際に, タイピング等による菌株の解析を行うた めにも分離培養は重要である ${ }^{23)}$. 当院では今回分離培 養は行っておらず院内感染の確定はできなかった.

偽膜性大腸炎の有効な治療法は，原因薬剤の中止と 塩酸バンコマイシンまたはアメーバ赤痢治療薬として 知られているメトロニダゾールの内服である．塩酸バ ンコマイシンは $2 \mathrm{~g} /$ 日を 6 時間おきに内服投与する. 症状が回復した後でも $7 \sim 14$ 日間は内服を続けるこ とで，偽膜性大腸炎の再発を防ぐことができる．メ卜 ロニダゾールは $1000 \mathrm{mg} /$ 日を 6 時間おきに内服投与 するが，偽膜性大腸炎に対しては保険適応外である. 上記の内服と併せて乳酸菌製剂も腸内細菌叢の維持に 有効である. 絶食や止痢薬投与は基本的に行わない. 偽膜性腸炎が劇症化して麻痺性イレウスとなった場合, 大腸切除を行ったとしても，急激に悪化し救命しえな いことも多い.このため, 早期発見, 早期治療が重要 である.
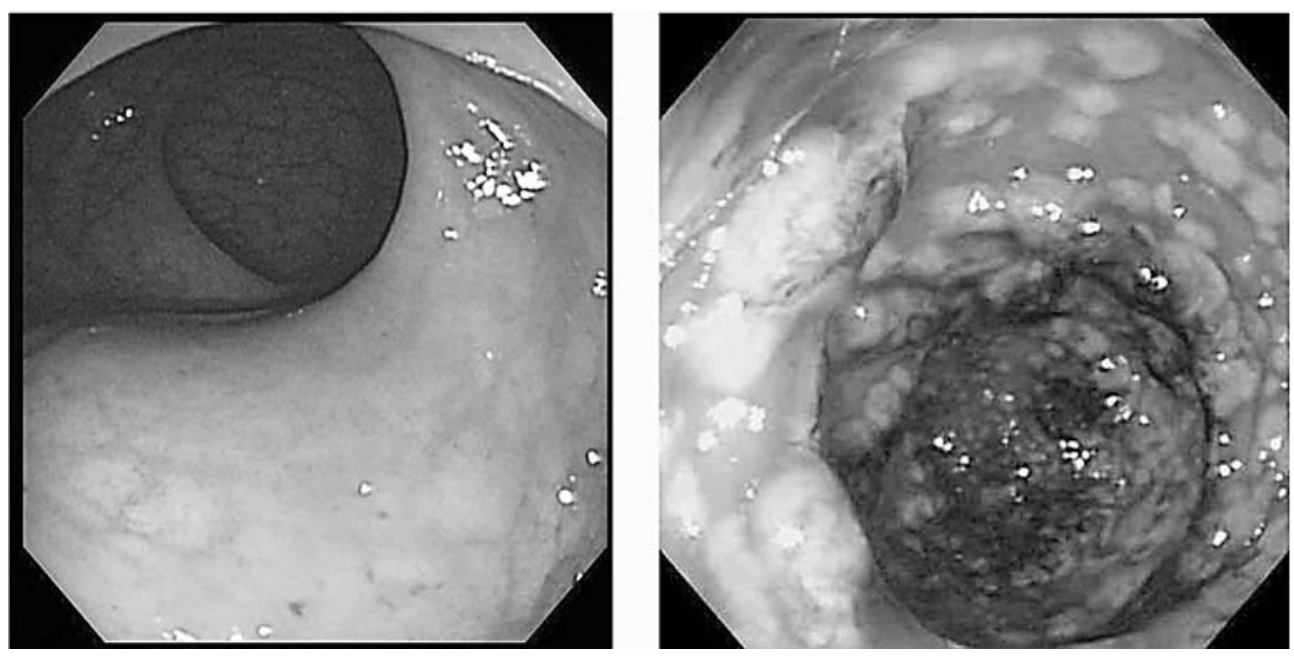

図 1 大腸内視鏡所見 (左：正常 右：偽膜性大腸炎) 


\section{ま と め}

(1)高齢者の大腿骨近位部骨折 95 例の術後偽膜性大 腸炎の発生について調査した.

(2) 8 例に偽膜性大腸炎が発症し，うち 2 例が死亡し た.

(3)術後 $\beta$-ラクタマーゼ阻害薬配合剂の使用が，発 症に関与していると考えられた。

(4)院内感染の可能性もあり, 媒体の除菌, 清潔化が 望まれる。

\section{参 考 文 献}

1) Dale N. Gerding, Stuart Johnson: Clostridium difficile 関連腸炎. ハリソン内科学第2版, pp.795-798. 黒川清監修，東京，メディカルサイエンスインターナショ ナル, 2003.

2) 加藤はる：話題の感染症：Clostridium difficileによ る院内感染. 環境感染, $22: 81,2007$.

3）目黒美保ら：Clostridium difficile 関連腸炎に対する 感染対策の検討。環境感染， $22: 249,2007$.

4）日本整形外科学会診療ガイドライン委員会 : 術後 SSI 予防のために第一選択とする抗菌薬は何か。骨・関節術 後感染予防ガイドライン, pp.61-63。骨・関節術後感染 予防ガイドライン策定委員会編集，小立鉦彦発行，東京， 南江堂, 2006.

5）品川長夫 : 術後感染防止のための抗菌薬選択. Jpn. J. Antibiot., 57(1) : 11-32, 2004. 